\title{
Efek Pencairan Kembali terhadap pH, Susut Masak dan Warna Daging Sapi Bali yang Dibekukan
}

\author{
(Effect of Thawing on pH, Cooking Loss, and Color of Bali Cattle Frozen Beef)
}

\author{
Hafid H, Napirah A, Meliana L \\ Fakultas Peternakan, Universitas Halu Oleo \\ Jl. HEA Mokodompit No. 1, Kampus Hijau Bumi Tridharma, Anduonohu, Kendari, Sulawesi Tenggara \\ harapinhafid@yahoo.co.id
}

\begin{abstract}
Beef is one of the protein source in human food. Usually, to be stored for a long time, the beef is frozen first, then thawed back before use. This research was aimed to study the effect of several thawing methods on $\mathrm{pH}$, cooking loss, and color of Bali Cattle frozen beef, especially from the longisimus dorsi part. Several thawing methods used were kept the frozen beef at room temperature $\left(28-30^{\circ} \mathrm{C}\right)(\mathrm{T} 1)$, soaked in water $(\mathrm{T} 2)$, and soaked in warm water $\left(60^{\circ} \mathrm{C}\right)(\mathrm{T} 3)$. The data obtained were analyzed using variance analysis based on completely randomized design with 3 treatments and 5 replications, and continued using least significant different test. The result showed that the using of several thawing methods did not give any significant effect $(\mathrm{P}>0,05)$ on beef $\mathrm{pH}$, but give significant effect $(\mathrm{P}<0,05)$ on cooking loss and color of beef. The lowest cooking loss were found on thawing used warm water (T3) and brightest color were found on thawing in room temperature (T1).
\end{abstract}

Key Words: Thawing, pH, Cooking Loss, Beef Color, Bali Cattle

\begin{abstract}
ABSTRAK
Daging sapi merupakan salah satu pangan sumber protein hewani yang banyak dikonsumsi manusia. Biasanya agar dapat disimpan dalam waktu lama, daging terlebih dahulu dibekukan, kemudian dicairkan kembali sebelum digunakan. Penelitian ini bertujuan mengetahui pengaruh beberapa metode pencairan kembali terhadap $\mathrm{pH}$, susut masak dan warna daging sapi Bali bagian longisimus dorsi. Perlakuan yang dicobakan adalah penyegaran kembali daging sapi beku dengan didiamkan pada suhu kamar $\left(28-30^{\circ} \mathrm{C}\right)(\mathrm{T} 1)$, direndam dalam air biasa (T2), direndam dalam air hangat $\left(60^{\circ} \mathrm{C}\right)(\mathrm{T} 3)$. Data yang diperoleh dianalisis menggunakan rancangan acak lengkap dengan 3 perlakuan dan 5 ulangan, serta dilanjutkan dengan uji beda nyata terkecil. Hasil penelitian menunjukkan bahwa penyegaran kembali dengan metode berbeda tidak memberikan pengaruh nyata $(\mathrm{P}>0,05)$ terhadap $\mathrm{pH}$ daging, tetapi memberikan pengaruh $(\mathrm{P}<0,05)$ terhadap susut masak dan warna daging. Susut masak paling rendah diperoleh pada perlakuan penyegaran dengan air hangat (T3) dan warna daging paling cerah diperoleh pada perlakuan penyegaran pada suhu kamar (T1).
\end{abstract}

Kata Kunci: Penyegaran Kembali, pH, Susut Masak, Warna Daging, Sapi Bali

\section{PENDAHULUAN}

Sapi Bali merupakan ternak sapi potong lokal yang banyak dijumpai di Sulawesi Tenggara. Jenis ternak ini banyak diperlihara karena mampu beradaptasi dengan lingkungan yang cukup panas, pakan rendah kualitas yang berupa rumput alam dan limbah pertanian maupun perkebunan yang belum terolah, namun cukup menguntungkan sebagai investasi karena dapat berkembang biak dan harganya selalu meningkat karena populasi semakin berkurang dan karena mempunyai nilai konsumsi tinggi pada waktu tertentu bagi konsumen beragama Islam (Hafid 2008). 
Daging sapi merupakan hasil utama ternak sapi potong yang diperoleh setelah proses penyembelihan secara halal, pengeluaran bagian bukan karkas (offal), pengkarkasan (dressing) dan dipisahkan dari karkas (boneless) (Hafid 2011). Daging termasuk bahan pangan yang mewah, mahal (expensive) akan tetapi tetap menjadi bahan lauk primadona dan menjadi tolok ukur mewahnya suatu pesta. Demikian pula bisa diolah menjadi berbagai macam jenis produk olahan dan masakan (lauk),

Sebagai sumber protein hewani, daging sapi Bali telah banyak dikonsumsi oleh masyarakat. Umumnya, agar dapat disimpan dalam waktu lama, daging disimpan dalam bentuk beku, kemudian disegarkan kembali (thawing) sebelum diolah lebih lanjut untuk dikonsumsi. Widati (2008) menyatakan bahwa daging beku merupakan salah satu alternatif pengawetan daging karena dapat menghambat proses kerusakan daging.

Suryaningsih (2010) menyatakan bahwa terdapat beberapa macam metode thawing, antara lain thawing pada suhu refrigerasi $\left(5-7^{\circ} \mathrm{C}\right)$, suhu air dingin $\left(10-15^{\circ} \mathrm{C}\right)$, suhu udara terbuka $\left(27-30^{\circ} \mathrm{C}\right)$, dan perendaman dengan air hangat. Perlu kewaspadaan yang tinggi saat pencairan kembali daging beku karena sangat besar kemungkinan terjadi kontaminasi mikroorganisme utamanya bakteri melalui wadah, air dan peralatan. Kalau hal ini terjadi maka sangat merugikan karena kualitas akan rusak karena cepat terjadi proses pembusukan.

Metode penyegaran kembali yang kurang tepat akan mempengaruhi kualitas daging. Soeparno (2011) menyatakan bahwa nutrien daging beku akan terlarut dalam air dan hilang bersama cairan daging yang keluar selama proses penyegaran kembali yang disebut sebagai drip. Oleh karena itu, diperlukan penelitian lebih lanjut mengenai pengaruh metode thawing terhadap kualitas daging yang merupakan tujuan dari penelitian ini.

\section{MATERI DAN METODE}

Penelitian dilaksanakan pada bulan Januari - Maret 2016 di Laboratorium Teknologi Hasil Ternak Fakultas Peternakan Universitas Halu Oleo.

Penelitian disusun berdasarkan rancangan acak lengkap (completely randomized design). Materi daging yang digunakan adalah daging sapi Bali bagian longisimus dorsi. Masing-masing seratus gram daging untuk setiap ulangan perlakuan, terlebih dahulu dipisahkan dari lemak, kemudian disimpan di dalam freezer selama 24 jam. Setelah beku daging disegarkan kembali dengan 3 metode berbeda sebagai perlakuan, yaitu: penyegaran kembali pada suhu kamar $\left(28-30^{\circ} \mathrm{C}\right)(\mathrm{T} 1)$, penyegaran dengan perendaman pada air biasa (T2), dan penyegaran dengan perendaman pada suhu kamar $\left(60^{\circ} \mathrm{C}\right)$ (T3). Penyegaran kembali dilakukan selama 3 jam. Masing-masing perlakuan diulang sebanyak 5 kali. Daging yang telah disegarkan kemudian diamati $\mathrm{pH}$, susut masak, dan warna daging.

Pengukuran $\mathrm{pH}$ dilakukan dengan menggunakan pH meter (Soeparno 2011). Penentuan susut masak dilakukan dengan membandingkan bobot daging sebelum dan setelah pemasakan. Susut masak dihitung dengan menggunakan rumus berikut:

$$
\text { Susut masak }(\%)=\frac{\text { berat daging sebelum dimasak }- \text { berat daging setelah dimasak }}{\text { berat daging sebelum dimasak }} \times 100 \%
$$

Sementara itu, warna daging ditentukan dengan menggunakan skor warna daging. Data selanjutnya dianalisis sidik ragam dan apabila terdapat pengaruh yang nyata pada perlakuan maka dilanjutkan dengan uji beda nyata terkecil (least significant different). 


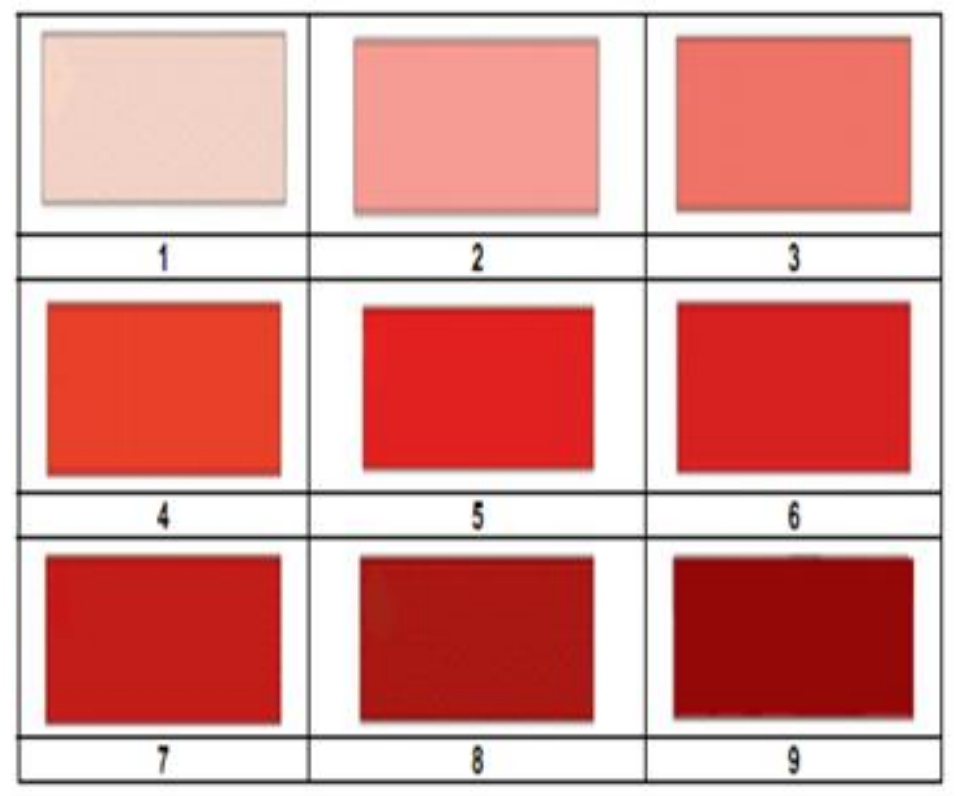

Gambar 1. Standar warna daging sapi berdasarkan SNI 3932: 2008

\section{HASIL DAN PEMBAHASAN}

Hasil analisis data menunjukkan bahwa metode penyegaran kembali tidak memberikan pengaruh $(\mathrm{P}>0,05)$ terhadap $\mathrm{pH}$ daging (Tabel 1). Nilai $\mathrm{pH}$ daging yang

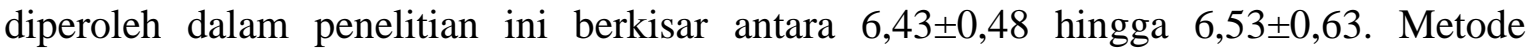
penyegaran kembali yang berbeda tidak memberikan pengaruh terhadap ph daging. Hal ini menunjukkan bahwa daging beku yang telah dicairkan dengan metode yang berbeda, mempunyai $\mathrm{pH}$ yang relatif sama, yang berarti belum ada pengaruh lingkungan luar terutama cemaran bakteri terhadap daging beku yang dicairkan. $\mathrm{pH}$ daging yang diperoleh dalam penelitian ini tergolong kurang baik. Buckle et al. (2009) menyatakan bahwa apabila $\mathrm{pH}$ daging sapi 5,1-6,1 maka daging lebih stabil terhadap kerusakan oleh mikroba, sedangkan apabila $\mathrm{pH}$ daging sapi berada sekitar 6,2-7,2 maka memungkinkan untuk pertumbuhan mikroba. Feiner (2006) menyebutkan bahwa secara umum, pH daging dan produk olahannya berkisar 4,6-6,4.

Hasil penelitian menunjukkan bahwa metode penyegaran kembali tidak memberikan pengaruh nyata terhadap susut masak daging sapi. Hal ini berarti susut masak daging sapi beku setelah penyegaran kembali pada suhu kamar tidak berbeda baik dengan penyegaran kembali menggunakan air biasa maupun dengan penyegaran kembali menggunakan air hangat. Susut masak pada daging menunjukkan kemampuan daging untuk mempertahankan kandungan airnya. Meskipun demikian, data susut masak sekitar 25,94-46,2 yang dihasilkan dalam penelitian tergolong tinggi, yang berarti bahwa daging yang telah dibekukan dalam penelitian ini sudah rusak struktur jaringannya sehingga air yang terikat dengan protein maupun air tidak bergerak dalam daging (immobile) tak mampu mempertahankannya dan keluar bersama air bebas (free water) yang terdapat pada permukaan daging pada saat dikenai perlakuan penyegaran kembali (thawing). Sebagaimana dikemukakan Aberle et al. (2001) maupun Buckle et al. (2009) bahwa ada tiga jenis air di dalam daging yaitu air yang terikat dengan protein, air tidak bergerak dalam daging (immobile), dan air bebas (free water). Secara fisik, semakin rendah susut masak, semakin baik kualitas daging. 
Tabel 1. Rata-rata $\mathrm{pH}$ daging, susut masak (\%) dan warna daging dengan metode penyegaran kembali yang berbeda

\begin{tabular}{lccc}
\hline \multirow{2}{*}{ Ulangan } & \multicolumn{3}{c}{ Metode penyegaran kembali } \\
\cline { 2 - 4 } pH daging & \multicolumn{3}{c}{$\mathrm{T} 2$} \\
\hline 1 & 6,71 & 6,56 & 5,67 \\
2 & 5,60 & 6,58 & 6,09 \\
3 & 6,79 & 6,14 & 6,88 \\
4 & 6,55 & 6,68 & 6,82 \\
5 & 6,47 & 6,55 & 7,19 \\
\hline Rataan & $6,43 \pm 0,48$ & $6,50 \pm 0,21$ & 21,00 \\
\hline Susut masak $(\%)$ & & & 31,10 \\
\hline 1 & 29,90 & 46,60 & 39,60 \\
2 & 47,80 & 41,70 & 48,30 \\
3 & 41,30 & 25,80 & 44,90 \\
4 & 38,70 & 42,50 & $36,98 \pm 11,04$ \\
5 & 41,00 & 36,20 & \\
\hline Rataan & $39,74 \pm 6,46$ & $38,56 \pm 8,04$ & 2,40 \\
\hline Warna daging & & & 2,60 \\
\hline 1 & 5,40 & 3,40 & 2,40 \\
2 & 5,40 & 2,80 & 2,20 \\
3 & 4,20 & 3,40 & 2,00 \\
4 & 4,60 & 3,00 & $2,32 \pm 0,23^{\mathrm{c}}$ \\
5 & 5,40 & 3,20 & \\
\hline Rataan & $5,00 \pm 0,57^{\mathrm{a}}$ & $3,16 \pm 0,26^{\mathrm{b}}$ & \\
\hline & & & \\
\hline & & & \\
\hline
\end{tabular}

Superskrip berbeda pada baris yang sama menunjukkan perlakuan berbeda nyata $(\mathrm{P}<0,05)$

Hasil penelitian menunjukkan bahwa warna daging sapi dipengaruhi $(\mathrm{P}<0,05)$ oleh metode penyegaran kembali yang digunakan. Penyegaran kembali dengan cara didiamkan pada suhu kamar memperlihatkan warna daging merah cerah, penyegaran daging dengan air biasa memperlihatkan warna merah pudar, sedangkan penyegaran daging dengan perendaman pada air hangat memperlihatkan warna daging yang merah pucat. Warna daging paling baik diperoleh pada perlakuan penyegaran pada suhu kamar. Kuntoro et al. (2013) menyebutkan bahwa konsumen menyukai daging dengan warna merah cerah yang menunjukkan mutu daging. Lebih lanjut, Lawrie (2003) menyatakan bahwa konsentrasi pigmen mioglobin pada daging merupakan faktor penentu utama warna daging. Jeong et al. (2009) dalam Kuntoro et al. (2013) menjelaskan bahwa ketika daging terekspos pada udara terbuka $\left(\mathrm{O}_{2}\right)$ akan terjadi rekasi antara mioglobin dengan oksigen sehingga menghasilkan warna merah cerah pada daging, tetapi bila terekspos terlalu lama, maka daging akan berwarna cokelat. 


\section{KESIMPULAN}

Hasil penelitian menunjukkan bahwa metode penyegaran kembali daging Sapi Bali beku memberikan pengaruh terhadap warna daging tetapi tidak memberikan pengaruh terhadap $\mathrm{pH}$ daging dan susut masak. Warna daging paling cerah diperoleh pada perlakuan penyegaran pada suhu kamar $\left(28-30^{\circ} \mathrm{C}\right)$.

\section{DAFTAR PUSTAKA}

Aberle DE, Forrest JC, Gerrard DE, Mills EW. 2001. Principles of meat science. Fourth edition. San Francisco (USA): W.H. Freeman and Company.

Buckle KA, Edwards, Fleet, Wootton. 2009. Ilmu pangan. Purnomo H, Adiono, penerjemah. Jakarta (Indonesia): UI Press.

Feiner G. 2006. Meat products handbook, Practical science and technology. Cambridge (UK): Woodhead Publishing Ltd.

Hafid H. 2008. Strategi Pengembangan Peternakan Sapi Potong di Sulawesi Tenggara dalam Mendukung Pencapaian Swasembada Daging Nasional. Orasi Ilmiah Pengukuhan Guru Besar. Kendari (Indonesia): Universitas Haluoleo.

Hafid H. 2011. Pengantar evaluasi karkas. Cetakan I. Kendari (Indonesia): Universitas Haluoleo Press.

Kuntoro B, Maheswari, Nuraini H. 2013. Mutu fisik dan mikrobiologi daging sapi asal rumah potong hewan (RPH) Kota Pekanbaru. J Peternak. 10:1-8.

Lawrie RA. 2003. Ilmu daging. Parakasi A, penerjemah. Jakarta (Indonesia): Universitas Indonesia Press.

Soeparno 2011. Ilmu dan teknologi daging. Yogyakarta (Indonesia): Gadjah Mada University Press.

Suryaningsih L. 2010. Kajian berbagai metoda thawing terhadap keempukan, daya ikat air, dan susut masak daging sapi bagian paha. Prosiding Seminar Nasional Fakultas Peternakan Unpad ke-2 "Sistem Produksi Berbasis Ekonomi Lokal". Bandung, 3-4 November 2010. Bandung (Indonesia): Universitas Padjadjaran. hlm. 630-634.

Widati AS. 2008. Pengaruh pelayuan, temperatur pembekuan, dan bahan pengemas terhadap kualitas kimia daging sapi beku. J Ilmu Teknol Hasil Ternak. 3:39-49.

\section{DISKUSI}

\section{Pertanyaan}

1. Kenapa warna daging yang di thawing pada suhu kamar warnanya lebih cerah?

2. Apakah fungsi pengukuran pH dalam penyimpanan daging di freezer?

\section{Jawaban}

1. Karena proses pencairan kembalinya secara alami sehingga menimbulkan warna daging yang lebih cerah.

2. Untuk mengetahui kondisi pH normal dan meyakinkan bahwa daging belum terjadi proses pembusukan. 